FOUNDATION CENTER

Knowledge to build on.

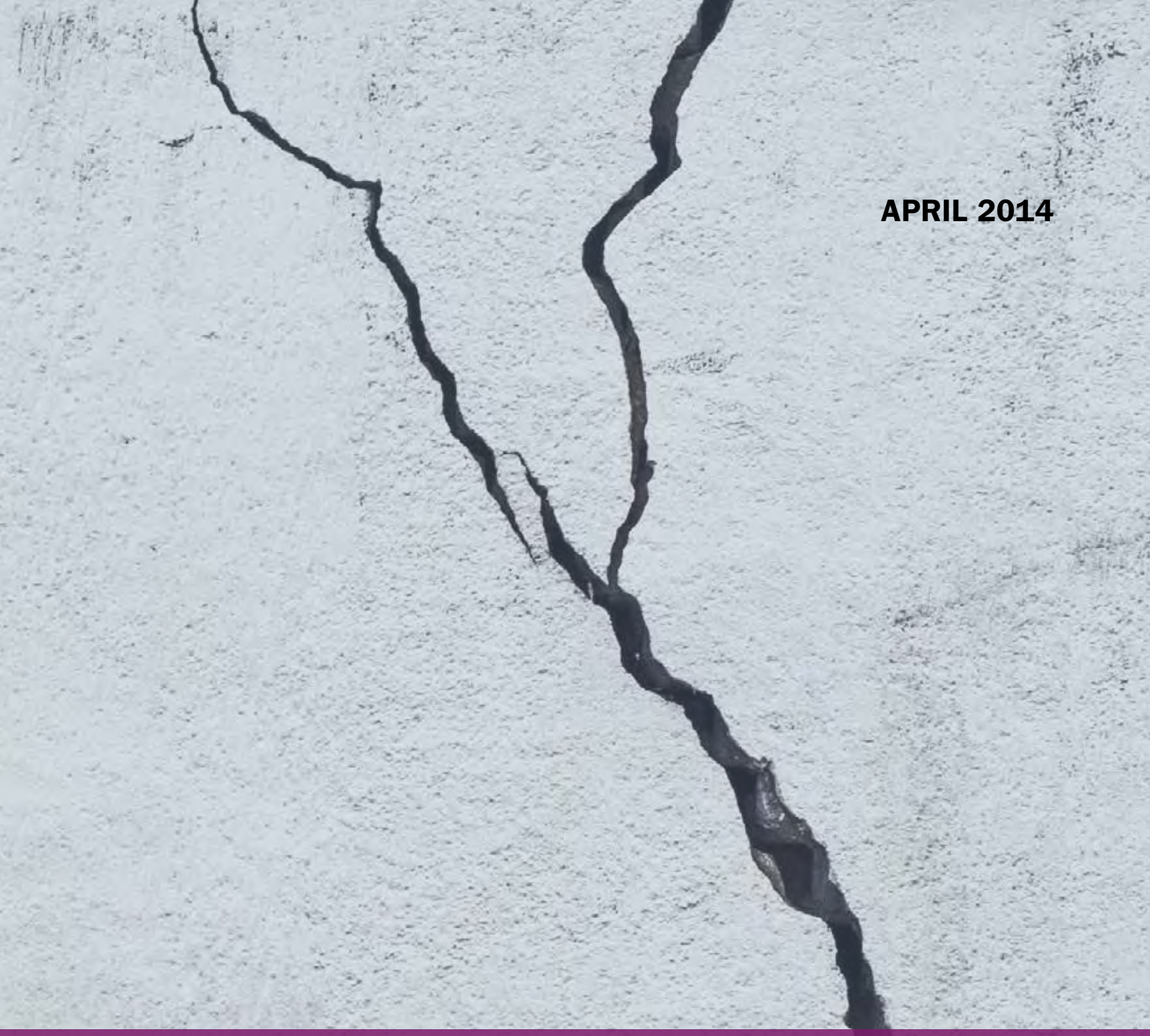

\title{
Foundation Funding to Address Domestic Violence in California
}




\section{AUTHORS \& CONTRIBUTORS}

\section{Authors}

Brenda Henry-Sanchez

Reina Mukai

\section{Contributors}

Janet Camarena

Ganga Dharmappa

Steven Lawrence

Sarah Reibstein

Betty Saronson

Vanessa Schnaidt

David Wolcheck
Director of Research for Special Projects

Research Manager

Director of San Francisco Office

Regional Training Specialist

Director of Research

Research Assistant

Graphic Designer/Production Coordinator

Director of Communications

Research Associate

\section{ABOUT THE FOUNDATION CENTER}

Established in 1956 and today supported by close to 550 foundations, the Foundation Center is the leading source of information about philanthropy worldwide. Through data, analysis, and training, it connects people who want to change the world to the resources they need to succeed. The Center maintains the most comprehensive database on U.S. and, increasingly, global grantmakers and their grants - a robust, accessible knowledge bank for the sector. It also operates research, education, and training programs designed to advance knowledge of philanthropy at every level. Thousands of people visit the Center's web site each day and are served in its five library/learning centers and at more than 470 Funding Information Network locations nationwide and around the world. For more information, please visit foundationcenter.org or call (212) 620-4230.

\section{ACKNOWLEDGEMENTS}

This research was made possible through support from Blue Shield of California Foundation.

(c) 2014 The Foundation Center. All rights reserved. 


\section{TABLE OF CONTENTS}

4 Introduction

5 Trends in Foundation Funding to Address Domestic Violence in California, 2002 to 2011

\section{FUNDING TO ADDRESS DOMESTIC VIOLENCE, 2009 TO 2011}

$\underline{7}$ Top Funders

9 Funding by Foundation Type

10 Top Recipient Organizations

11 Funding by County

13 Funding by Issue Area

14 Funding by Population Group

16 Funding by Types of Support

17 Endnotes

\section{APPENDIX TABLES}

\section{BOXES}

7 Quick Facts on Foundation Funding to Address Domestic Violence in California 2009-2011

9 Public Foundations

14 Funding for Domestic Violence Prevention

17 About the Foundation Center Grants Sample 


\section{INTRODUCTION}

The emotional, physical, and mental health consequences of domestic violence are numerous and ripple not only through generations of families directly impacted, but through communities and society overall. Programs and policies that enable survivors and their families to access services and escape violence are critical to breaking the cycle of violence for future generations. Education and prevention are increasingly important to promote healthy relationships.

\section{DOMESTIC VIOLENCE STATISTICS}

The National Intimate Partner and Sexual Violence Survey estimates that

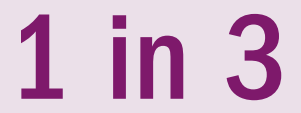

California women will experience rape, physical violence, and/or stalking by an intimate partner in their lifetime. ${ }^{1}$

In 2011, California law enforcement received

$$
158,548
$$

domestic violence-related calls. ${ }^{2}$

The National Network to End Domestic Violence 2011 domestic violence census found that, in a 24-hour period, California domestic violence

$$
\text { programs served }
$$

women and children; there were an additional

$$
924
$$

requests for services that were unmet. ${ }^{3}$
Eliminating domestic violence in California will require partnership and collaboration among leaders, advocates, and practitioners from local and state government, community organizations, and organized philanthropy. To enable this work, Blue Shield of California Foundation commissioned the Foundation Center to prepare this first-ever examination of the role of U.S. foundations in addressing domestic violence-related issues in California.

\section{Eliminating domestic}

\section{violence in California}

\section{will require partnership}

and collaboration.

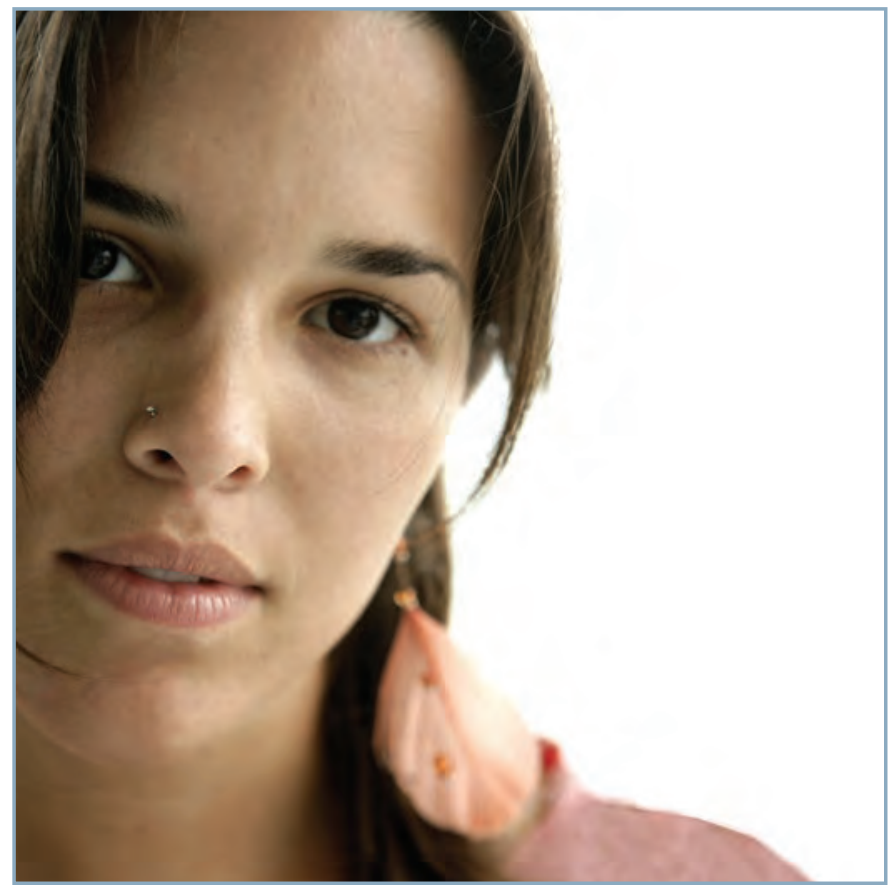




\section{TRENDS IN FOUNDATION FUNDING TO ADDRESS DOMESTIC VIOLENCE IN CALIFORNIA, 2002 TO 2011}

U.S. foundation funding to address domestic violence in California increased annually over most of the last decade. Foundation funding grew just over 40 percent from 2002 to 2011. Adjusted for inflation, funding rose 12.3 percent. In 2002, funders included in the Foundation Center's annual sample allocated 114 grants totaling \$8 million. (See 'About the Foundation Center Grants Sample' on page 17 for more details.) Annual giving by sampled foundations reached $\$ 10$ million by 2005 and steadily increased up until the economic downturn in 2008. Domestic violence-related giving in California returned to growth in 2010, reaching a peak of $\$ 18.1$ million. However, funding declined 37.9 percent to $\$ 11.3$ million in 2011.

Part of the drop in funding in 2011 was due to a surge in giving by Blue Shield of California Foundation in 2010, which reflects its biannual investment in core support awarded to every domestic violence shelter in California. The Foundation awarded 132 grants totaling $\$ 6.8$ million to address domestic violence in California in 2010 , compared to 26 grants totaling roughly $\$ 3.1$ million in 2011. ${ }^{4}$ The California Endowment also had a spike in 2010 with 36 grants totaling $\$ 1.4$ million.

Foundation Giving to Address Domestic Violence in California, 2002-2011
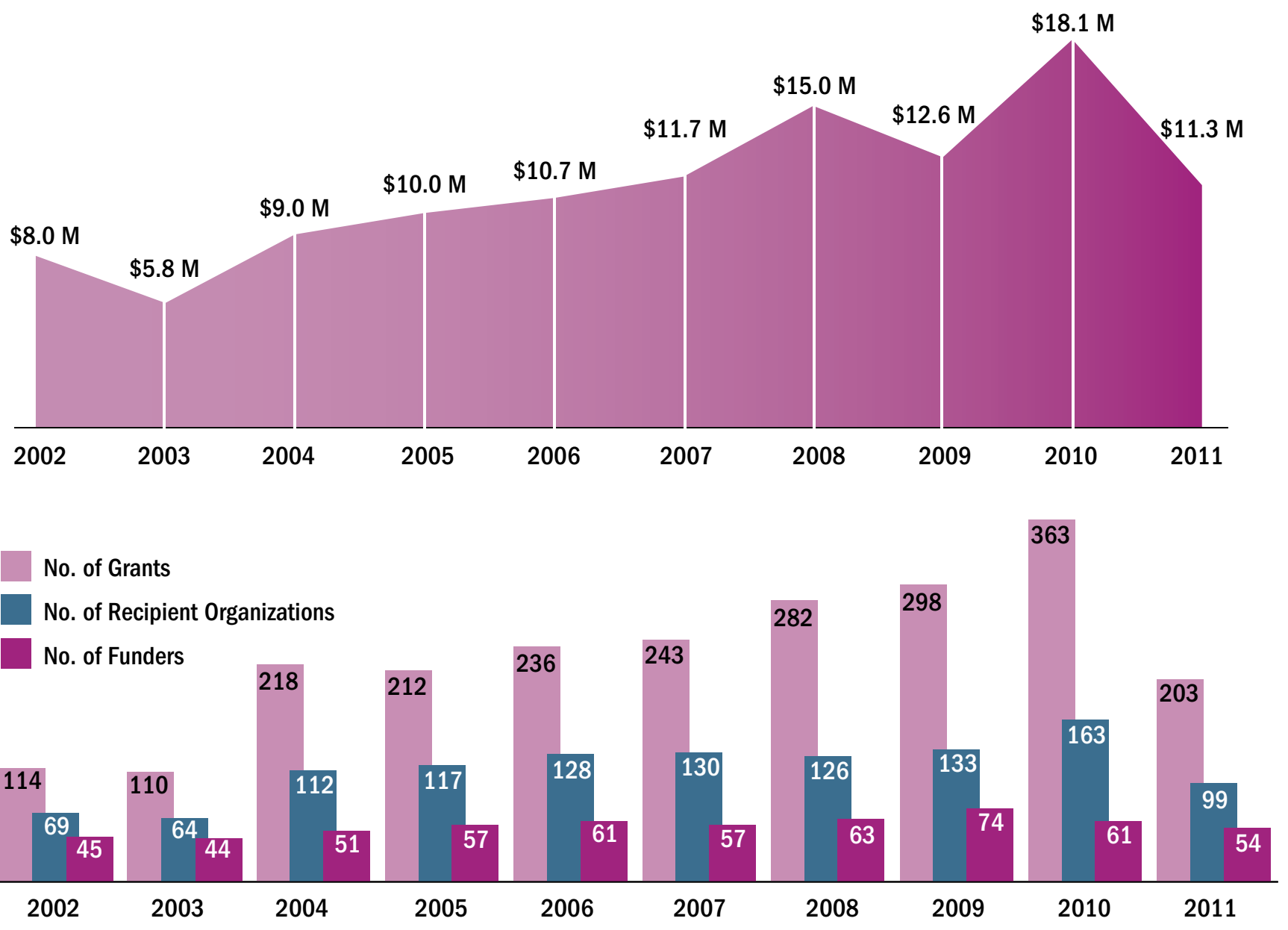

Source: The Foundation Center, 2014. Based on all grants of $\$ 10,000$ or more awarded by a national sample of larger U.S. foundations. For community foundations, only discretionary grants are included. Grants to individuals are not included in the file. 
Data for 2012 and beyond will be needed to determine whether the funding drop in 2011 is a fluke or indicative of a trend of decreased funding for the field.

The number of foundation grants to address domestic violence in California also steadily increased for much of the decade, reaching a peak of 363 grants in 2010 before declining 44.2 percent to 203 grants in 2011. As noted earlier, much of this change was driven by Blue Shield of California Foundation's biannual investment in core support to domestic violence shelters in 2010.

The number of funders awarding grants to address domestic violence in California has remained relatively steady throughout the decade. However, these grantmakers reflect a relatively small share of funders that award grants in California overall.
Foundation support to address domestic violence as a share of dollars awarded to California-based organizations has remained steady, capturing approximately 0.4 percent of overall dollars. In contrast, the share by number of grants has increased during this time period from 0.7 percent to 0.9 percent, with higher shares reported in the intervening years.

Federal funding is the main source of support for domestic violence initiatives in California. ${ }^{5}$ The state also provides resources through its general fund, which was established through law in 1977. However, the general fund was cut in 2009 , although funds were later restored.

\section{Share of Foundation Giving to Address Domestic Violence in California, 2002-2011}

Percent of Grants _ Percent of Grant Dollars

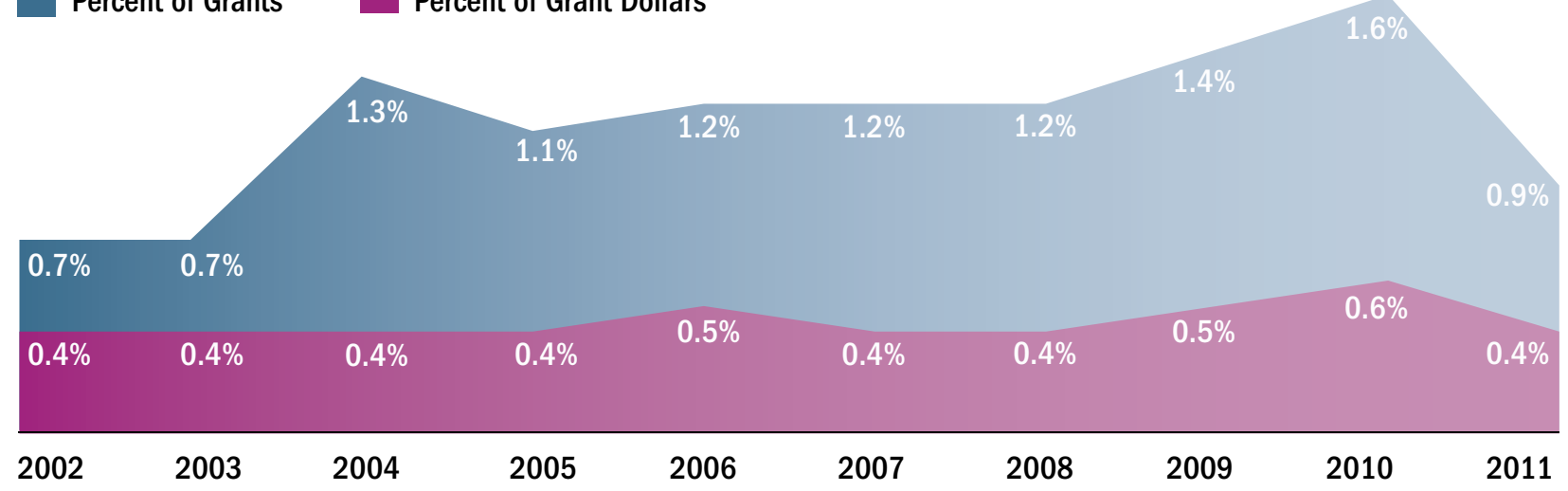

Funding to Address Domestic Violence in California, 2003-2011

Federal Funding (VAWA, VOCA, \& FVSPA) State General Fund (DVAP) _ Foundation Funding

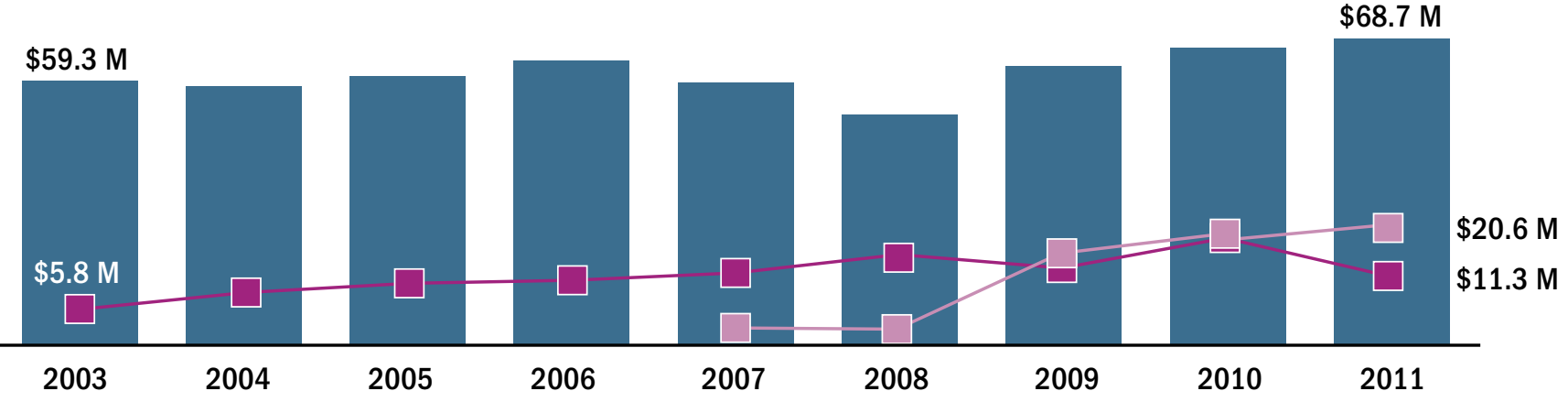

Sources: Federal Funding Data: Campaign for Funding to End Domestic and Sexual Violence, Appropriations Briefing Books (FY 2008, FY 2010, FY 2013); State General Fund Data: California Emergency Management Services, Joint Legislative Budget Committee Reports (2009, 2010, 2011, 2012, 2013); Foundation Funding Data: The Foundation Center: Based on all grants of $\$ 10,000$ or more awarded by a national sample of larger U.S. foundations. 


\section{FUNDING TO ADDRESS DOMESTIC VIOLENCE, 2009 TO 2011}

\section{The preceding analysis examined year-to-year changes in foundation giving to address domestic violence in California. The following analyses narrow the focus to the three-year period 2009 to 2011.}

\section{TOP FUNDERS}

From 2009 to 2011, large U.S. foundations provided just over $\$ 42$ million in support to California-based organizations to address domestic violence. This total includes giving focused on domestic violence prevention as well as grants for services provided to victims of domestic violence.

The top 10 funders accounted for nearly 70 percent of all dollars and 63 percent of all grants awarded. Eight of the top 10 funders by dollars were California-based foundations. California-based foundations accounted for over 77 percent of all dollars and grants awarded to address domestic violence. Blue Shield of California Foundation was the largest funder, awarding 250 grants totaling $\$ 13$ million, which was almost a third of all dollars awarded to domestic violence in the three-year period. The Foundation's largest award was a $\$ 1.5$ million grant to the San Francisco-based Women's Foundation of California to implement the Blue Shield Against Violence Strong Field Project Organizational Strengths grants program. The project is a four-year effort, started in 2010 , aimed at building a strong, coordinated network of domestic violence service providers in California.

The New Jersey-based Robert Wood Johnson Foundation ranked second with 6 grants totaling $\$ 2.9$ million. During this time, the Foundation made investments toward teen dating violence prevention programs that promote healthy relationships among teens as well as preventing intimate partner violence in immigrant and refugee communities.
QUICK FACTS ON FOUNDATION FUNDING TO ADDRESS DOMESTIC VIOLENCE IN CALIFORNIA, 2009-2011

TOTAL GRANT DOLLARS $\$ 42,058,330$

AVERAGE GRANT AMOUNT

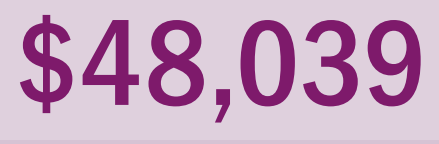

MEDIAN GRANT AMOUNT

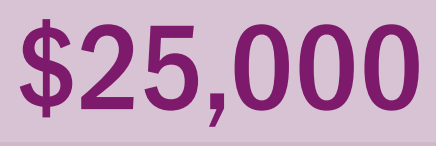

TOTAL NUMBER OF GRANTS

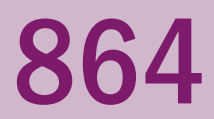

NUMBER OF UNIQUE RECIPIENT ORGANIZATIONS RECEIVING AT LEAST ONE GRANT

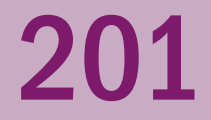

NUMBER OF SAMPLED FUNDERS PROVIDING AT LEAST ONE GRANT

Grantmaking to address domestic violence in California represents a small fraction of overall giving, even for most of the top funders active in the space. With the exception of Blue Shield of California Foundation, which allocated 15 percent of their total grantmaking to domestic violence, the rest of the top 10 foundations ranked by share of grantmaking allocated between 2 and 4.5 percent of their total grantmaking to address domestic violence in California. Nine of the 10 top funders by share were California-based foundations. 
Top 10 Foundations, 2009-2011

By Dollar Amount

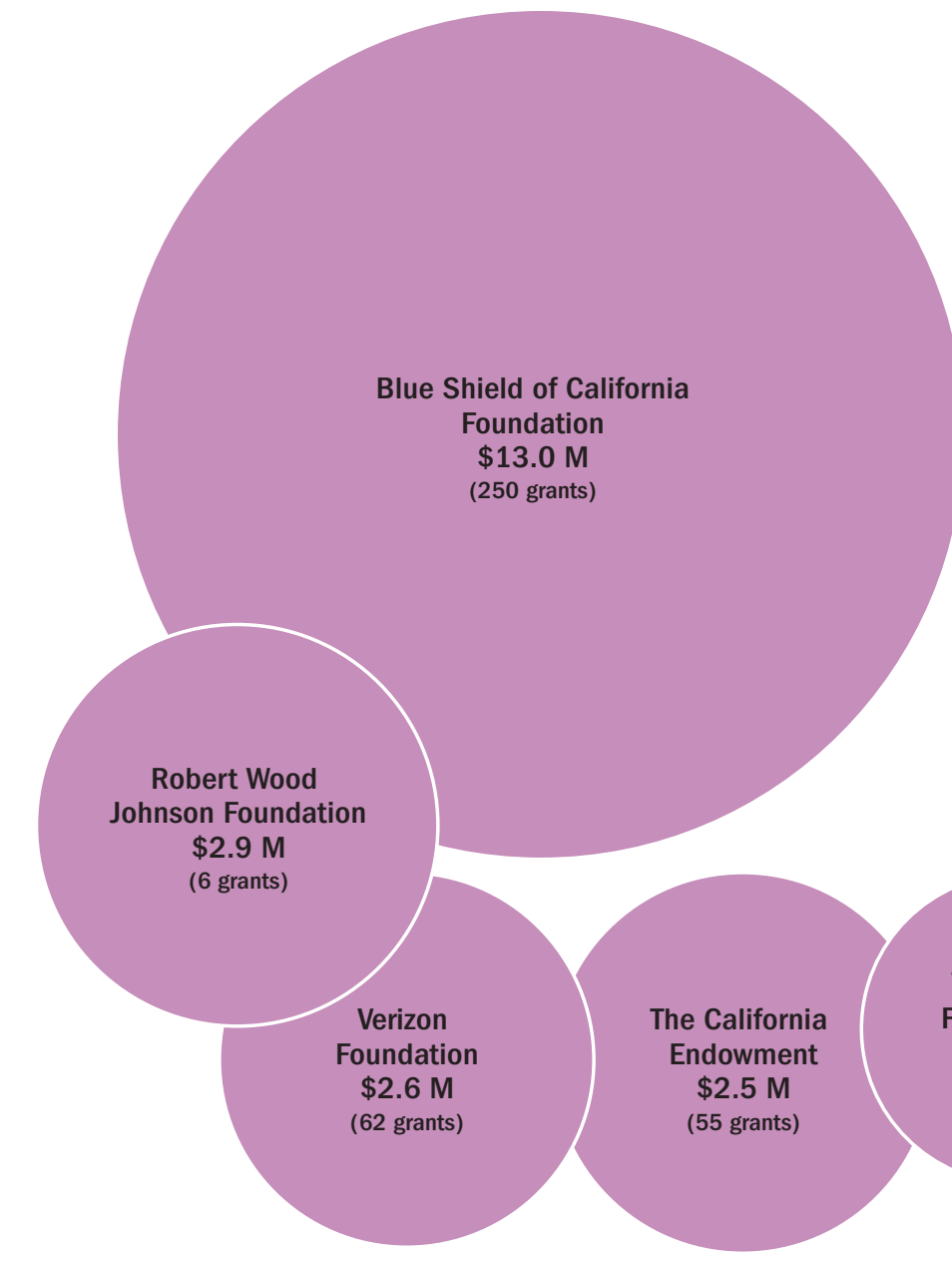

By Share of Foundation's Total Giving

\begin{tabular}{|lc}
\hline Blue Shield of California Foundation & $15.1 \%$ \\
\hline van Loben Sels/RembeRock Foundation & $4.5 \%$ \\
\hline Pacific Life Foundation & $3.8 \%$ \\
\hline Bella Vista Foundation & $3.3 \%$ \\
\hline Y \& H Soda Foundation & $2.9 \%$ \\
\hline Ralph M. Parsons Foundation & $2.3 \%$ \\
\hline Orange County Community Foundation & $2.3 \%$ \\
\hline Verizon Foundation & $2.2 \%$ \\
\hline Morris Stulsaft Foundation & $2.2 \%$ \\
\hline Weingart Foundation & $2.1 \%$ \\
\hline
\end{tabular}

Source: The Foundation Center, 2014. Based on all grants of $\$ 10,000$ or more awarded by a sample of 1,000 larger foundations. For a more comprehensive list of top funders by giving to California recipient organizations for domestic violencerelated issues, see Table 1 of the Appendix.

\section{Grantmaking to address domestic}

\section{violence in California represents a small}

\section{fraction of overall giving, even for most} of the top funders active in the space. 


\section{FUNDING BY FOUNDATION TYPE}

Independent and corporate foundations accounted for the largest shares of funding to address domestic violence in California in the 2009 to 2011 grants set (42.5 percent and 42.2 percent, respectively). Blue Shield of California Foundation and Verizon Foundation (both corporate foundations) were among the largest funders in the space and accounted for more than a third of the dollars awarded.

The composition of giving differs significantly compared to funding for California overall, where independent foundations account for 80 percent of grant dollars and corporate funders awarded less than 8 percent of dollars.

Community foundations accounted for roughly 15 percent of all domestic violence-related grants awarded to California recipients compared to 11.1 percent for California overall. Operating foundations represented the smallest share for domestic violencerelated funding in California and to the state overall (0.6 percent and 1.2 percent, respectively).
Giving by Foundation Type, 2009-2011

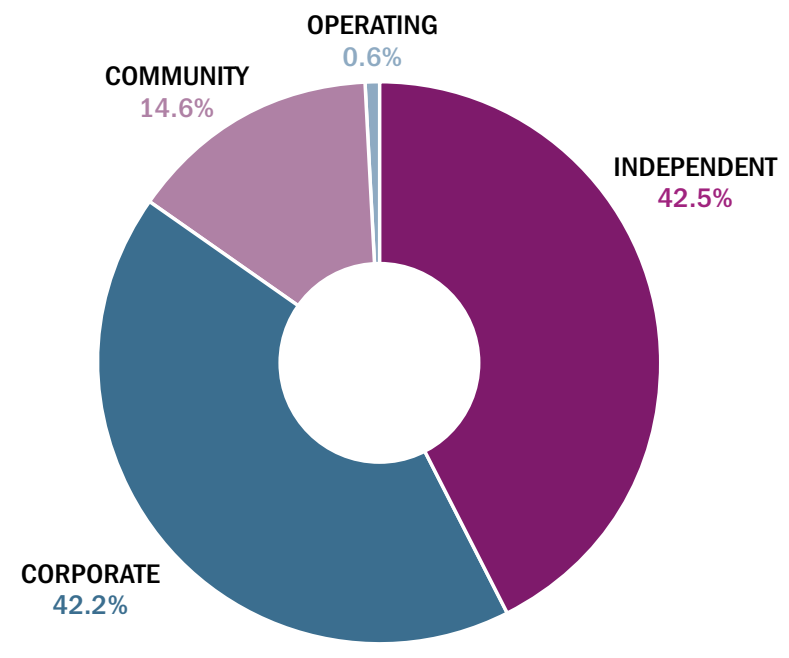

Total Dollars $=\$ 42.1$ Million

Source: The Foundation Center, 2014. Based on all grants of $\$ 10,000$ or more awarded by a sample of 1,000 larger foundations.

\section{PUBLIC FOUNDATIONS}

Public foundations, or grantmaking public charities, are similar to community foundations in that they both raise funds from the public and serve as grantmakers.

In addition to the $\mathbf{8 6 4}$ domestic violence-related grants of $\$ 10,000$ or more that were awarded to Californiabased recipient organizations between 2009 and 2011 by the largest U.S. foundations, there were several public foundations that provided funding to address domestic violence in California.

Examples include the Avon Foundation for Women, which operates several programs that address issues of domestic violence (e.g., Domestic and Sexual Assault Training Programs and Domestic Violence Survivor Empowerment
Program), and the Mary Kay Foundation, which provides support to raise awareness of the epidemic problem of violence against women.

The Women's Foundation of California, in particular, is a public foundation that awards grants and is involved in advocacy work to ensure all women in California achieve equity and economic security. Founded in 1979, the Foundation was an early supporter of domestic violence issues in California and continues to support this work through initiatives such as the Strong Field Project, a collaboration with Blue Shield of California Foundation at building a strong, coordinated network of domestic violence service providers in California. 


\section{TOP RECIPIENT ORGANIZATIONS}

The figure below ranks the top 10 California-based recipients of foundation giving to address domestic violence in the 2009 to 2011 sample. At the top of the list were Futures Without Violence and the Family Justice Center Alliance. The Family Justice Center Alliance provides training and technical assistance to over 80 Family Justice Centers and domestic violence professionals. These top 10 organizations received 40 percent of all dollars and 19 percent of all grants awarded by foundations. Among recipients benefiting from the greatest number of grants to address domestic violence were the Burlingame-based Community Overcoming Relationship Abuse (32 grants totaling $\$ 930,000$ ) and San Jose-based Next Door Solutions to
Domestic Violence (26 grants totaling $\$ 732,000)$. Both organizations provide housing and shelter solutions, legal services, counseling, and services for teens and youth.

The vast majority of grants awarded to address domestic violence in California were for organizations that provide family services for victims of domestic violence. These range from temporary emergency shelter for women who have experienced domestic violence and their children to domestic violence hotlines, accompaniment services, counseling for battered individuals, support groups, and transportation for people who are endangered to assistance in obtaining a temporary restraining order. Many grants were also awarded to organizations that deal specifically with the prevention of spouse abuse, including spousal sexual abuse.

Top 10 Recipients by Amount, 2009-2011

\begin{tabular}{llll}
\hline RECIPIENT ORGANIZATION & \multicolumn{1}{c}{ CITY } & AMOUNT & NO. OF GRANTS \\
\hline 1. Futures Without Violence & San Francisco & $\$ 6,011,443$ & 24 \\
\hline 2. Family Justice Center Alliance & San Diego & $2,676,400$ & 10 \\
\hline 3. Women's Foundation of California & San Francisco & $1,772,343$ & 4 \\
\hline 4. California Partnership to End Domestic Violence & Sacramento & $1,308,900$ & 10 \\
\hline 5. Jenesse Center & Los Angeles & 955,000 & 18 \\
\hline 6. Community Overcoming Relationship Abuse & Burlingame & 929,644 & 32 \\
\hline 7. CompassPoint Nonprofit Services & Oakland & 874,465 & 4 \\
\hline 8. Human Options & Irvine & 817,800 & 22 \\
\hline 9. Interval House & Long Beach & 760,500 & 18 \\
\hline 10. Next Door Solutions to Domestic Violence & San Jose & 732,279 & 26 \\
\hline
\end{tabular}

Source: The Foundation Center, 2014 . Based on all grants of $\$ 10,000$ or more awarded by a sample of 1,000 larger foundations. For a more comprehensive list of top California recipients of foundation grants to address domestic violence, see Table 2 of the Appendix. 
Top 10 Recipients by Number of Grants, 2009-2011

\begin{tabular}{|c|c|c|c|}
\hline RECIPIENT ORGANIZATION & CITY & NO. OF GRANTS & AMOUNT \\
\hline 1. Community Overcoming Relationship Abuse & Burlingame & 32 & $\$ 929,644$ \\
\hline 2. Next Door Solutions to Domestic Violence & San Jose & 26 & 732,279 \\
\hline 3. Futures Without Violence & San Francisco & 24 & $6,011,443$ \\
\hline 4. Human Options & Irvine & 22 & 817,800 \\
\hline 5. Laura's House & Ladera Ranch & 21 & 455,410 \\
\hline 6. Jenesse Center & Los Angeles & 18 & 955,000 \\
\hline 7. Interval House & Long Beach & 18 & 760,500 \\
\hline 8. Cornerstone Community Development Corporation & San Leandro & 16 & 405,075 \\
\hline 9. La Casa de las Madres & San Francisco & 15 & 437,075 \\
\hline 10. Domestic Violence Solutions for Santa Barbara County & Santa Barbara & 13 & 721,000 \\
\hline Convent of the Good Shepherd Shelter & Los Angeles & 13 & 505,000 \\
\hline STAND! Against Domestic Violence & Concord & 13 & 428,660 \\
\hline Center for Community Solutions & San Diego & 13 & 380,506 \\
\hline
\end{tabular}

Source: The Foundation Center, 2014. Based on all grants of $\$ 10,000$ or more awarded by a sample of 1,000 larger foundations.

\section{FUNDING BY COUNTY}

Funding was not evenly distributed to recipient organizations located throughout California's 58 counties. Recipients based in San Francisco County received the largest share of grant dollars to address domestic violence, capturing over $\$ 11.5$ million during the three-year period, followed by Los Angeles, San Diego, Alameda, and Sacramento Counties, respectively. Organizations located in these five counties received just over 70 percent of funding. In contrast, organizations in over half of the counties received less than $\$ 100,000$.
Although funding was not evenly distributed to recipients located across counties in California, organizations based in large metropolitan areas such as San Francisco have statewide reach, and therefore, dollars provided to these organizations are often used to provide services throughout the state.

Looking at regional patterns, funding was concentrated in organizations located in the San Francisco Bay area and Southern California. Less funding went to organizations in the Shasta Cascade, Gold Country, and the High Sierra. 
Funding by County, 2009-2011

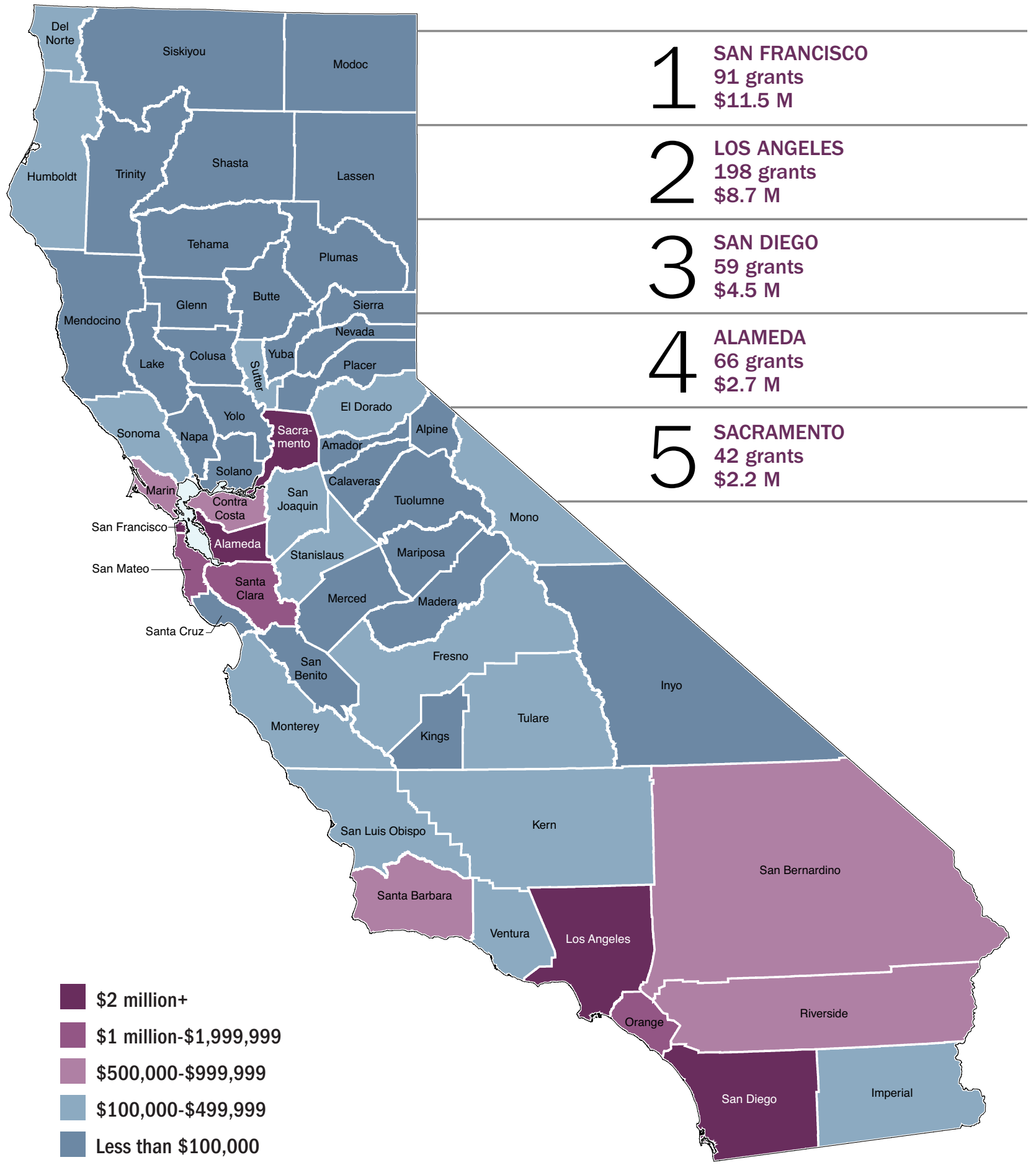

Source: The Foundation Center, 2014. Based on all grants of $\$ 10,000$ or more awarded by a sample of 1,000 larger foundations. For a more comprehensive list of top California counties receiving funding to address domestic violence, see Table 3 of the Appendix. 


\section{FUNDING BY ISSUE AREA}

Overall, human services and health were the top priorities within funding to address domestic violence in California. Almost all of the grants awarded to address domestic violence had a human services component, although grants also focused on other areas, such as health and education.

\section{Human Services}

The vast majority of U.S. foundation funding to address domestic violence in California supports direct services to abuse victims and their families, such as housing assistance, counseling,

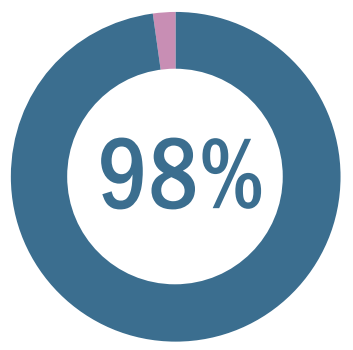
and legal services. Examples of human services grants include a $\$ 256,000$ award from the Leichtag Foundation in 2011 to the Encinitas-based Community Resource Center. The Center's mission is to provide families in need and victims of domestic violence with safety, stability, and a path to self-sufficiency.

In addition to direct service-related activities, advocacyrelated efforts geared toward increasing awareness and support for domestic violence victims and their families were also supported by foundations. Among the largest grants in this area was a $\$ 1$ million grant awarded by the Michigan-based Kresge Foundation in 2010 to Futures Without Violence, a national organization headquartered in San Francisco that focuses on ending violence against women and children.

\section{Health}

Close to a quarter (23.7 percent) of grants encompassed a healthrelated focus. The key areas of support included public health, mental health, and reproductive health care. An example includes

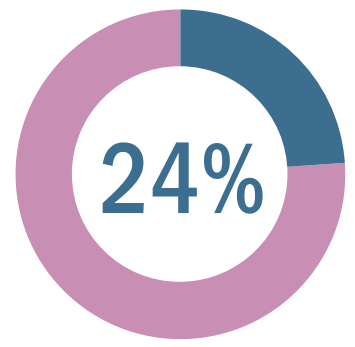
the $\$ 18,720$ grant awarded by the Sierra Health Foundation in 2011 to the Haven Women's Center of Stanislaus for clinical supervision of marriage and family therapist trainees and interns to provide counseling to assist survivors of domestic violence and sexual assault achieve and maintain social, emotional, and mental well-being.

\section{Public Affairs/Society Benefit}

Public affairs/society benefit, which encompasses civil rights and social action, community improvement and development, philanthropy and voluntarism, and public affairs, represented roughly 4 percent of grants awarded to

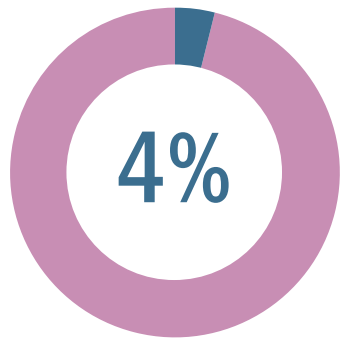
address domestic violence in California. Several grants awarded within this area were for veteran/ military organizations, such as one $\$ 125,073$ grant awarded in 2011 by Blue Shield of California Foundation to San Francisco-based Swords to Plowshares-an organization providing veteran services and advocacyfor Veteran Family Violence to increase awareness and access to services.

\section{Education}

Funding for education captured a relatively small share of grants (roughly 1.6 percent). Among grants made for education was a \$30,000 award in 2011 from the Silicon Valley Community Foundation to the San Jose-based

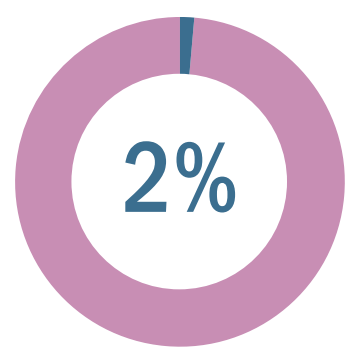
Next Door Solutions to Domestic Violence for digital literacy programming for the Youth Leadership Forum and cyber-safety program, as well as a $\$ 25,000$ grant in 2010 from Wal-Mart Foundation to the Los Angeles-based 1736 Family Crisis Center for education and skills training as part of a selfsufficiency program.

\section{Other}

Foundation grants to address domestic violence in California targeted areas beyond those noted above, such as the social sciences, religion, and arts and culture. Among grants made for these areas was a $\$ 50,000$ grant

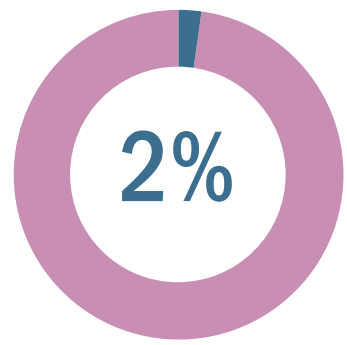
in 2011 for program support from the Green Foundation to A Window Between Worlds, an organization dedicated to using art to help end domestic violence.

See Table 4 of the Appendix for a full breakdown of domestic violence-related funding in California by issue area. Grants may be for multiple issue areas and therefore could be counted more than once. 


\section{FUNDING FOR DOMESTIC VIOLENCE PREVENTION}

While much of the funding activity was connected to providing direct services to domestic violence survivors and their families, a fair amount of grantmaking activity also focused on domestic violence prevention efforts. For example, the California Endowment awarded a $\$ 362,270$ grant in 2009 to Futures Without Violence for a youth violence prevention project, aimed at reducing disparate health outcomes associated with dating violence among U.S.-born Latino youth and a $\$ 350,000$ grant in $\mathbf{2 0 1 0}$ to the South Asian Network to focus on primary prevention of domestic violence. Similarly, the WoodClaeyssens Foundation awarded three grants to the Legal Aid Foundation of Santa Barbara County for domestic violence prevention. Lastly, the RGK Foundation, based in Austin, Texas awarded $\$ 20,000$ in 2009 to Break the Cycle to develop a Girl's Scout edition of a violence prevention curriculum.

\section{FUNDING BY POPULATION GROUP}

Foundation giving to address domestic violence in California focused on several different population groups. It comes as no surprise that almost all of the grants awarded focus on women and girls. Nonetheless, many of the grants also specified intent to benefit children and youth, the economically disadvantaged, ethnic/racial minorities, immigrants and refugees, and men and boys.

\section{Children and Youth}

Domestic violence not only impacts the targeted victim but also the victim's family, particularly the children of victims. Nearly three-quarters (73.5 percent) of grants awarded in California to address domestic violence specified a focus on children and youth. While much of this grantmaking supports organizations that provide services to both the victims and their families, it also provides funding for services specifically targeted for youth and teens. For example, in 2011 the Ahmanson Foundation awarded $\$ 75,000$ to House of Ruth, an organization that advocates for and assists women and children victimized by domestic violence and children exposed to violence, for their residential children's program, and in 2009, the Weingart Foundation awarded $\$ 100,000$ to Los Angeles-based Human Options for their joint parent-child treatment program, which services domestic violence clients in emergency and transitional housing.

\section{Economically Disadvantaged}

Victims of domestic violence disproportionately suffer economic challenges. Therefore, it is not surprising that over one-third (35 percent) of grants focused on the economically disadvantaged. Among grants focused on the economically disadvantaged was a $\$ 25,000$ grant from the Silicon Valley Community Foundation to the Legal Aid Society of San Mateo County for the New Beginning program, which provides free legal services to lowincome domestic violence survivors in San Mateo County. Another example is a $\$ 15,000$ grant from the Macy's Foundation to the Women's Initiative for Self Employment for Strive and Thrive, which provides microenterprise opportunities for domestic violence survivors.

\section{Domestic violence}

\section{not only impacts the} targeted victim but also the victim's family, particularly the children of victims. 


\section{Funding by Population Group, 2009-2011}
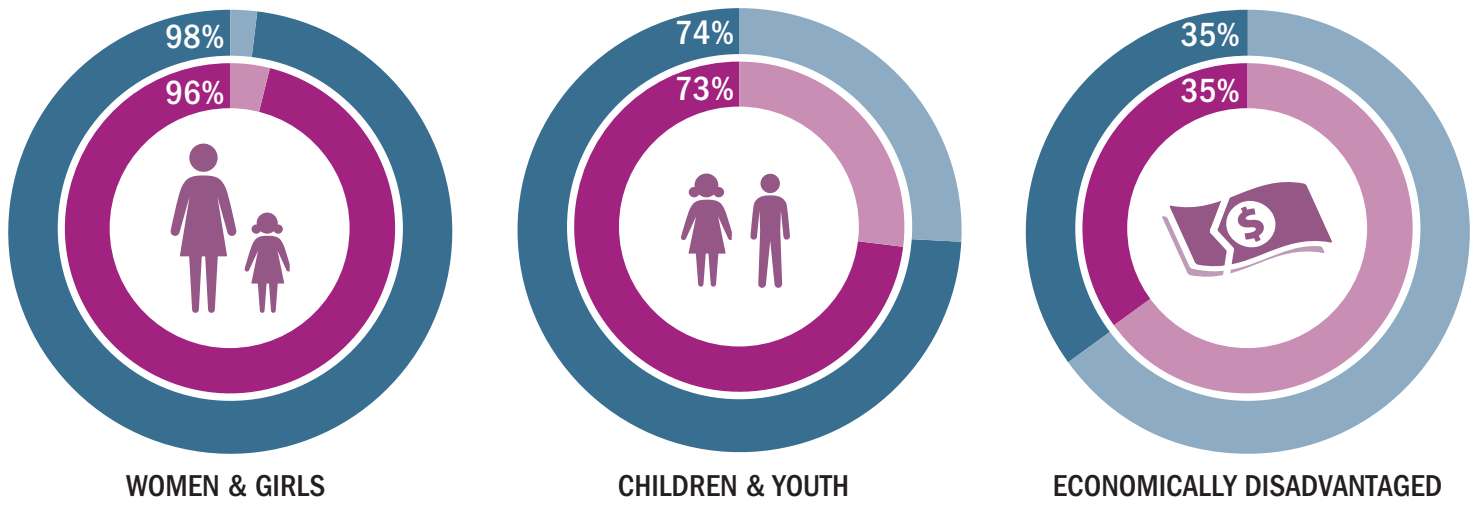

ECONOMICALLY DISADVANTAGED

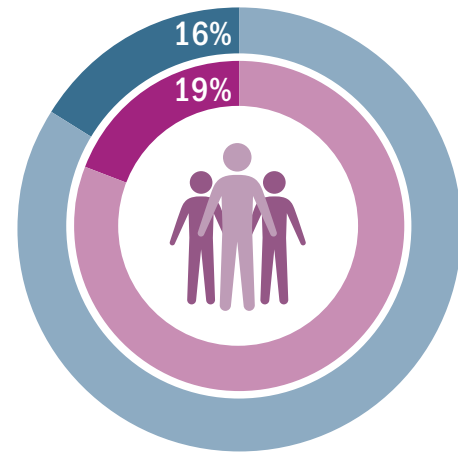

ETHNIC OR RACIAL MINORITIES

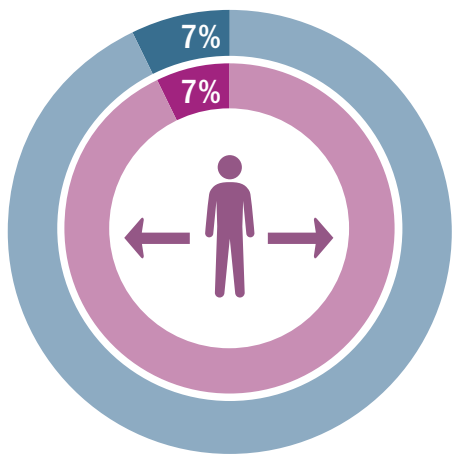

IMMIGRANTS \& REFUGEES

Source: The Foundation Center, 2014. Based on all grants of $\$ 10,000$ or more awarded by a sample of 1,000 larger foundations. See Table 5 of the Appendix for a full breakdown of domestic violence-related funding in California by specified population. Grants may benefit more than one population group and therefore may be counted more than once.

\section{Racial/Ethnic Minorities}

Roughly one-in-six foundation grants (16.1 percent) targeted a racial/ethnic minority population group. Asian/Pacific Islanders (6.3 percent) and Hispanic/ Latinos (2.9 percent) received the largest shares of grant dollars among specified racial/ethnic minority groups. Among the larger grants awarded to racial/ ethnic minorities was a $\$ 350,000$ award from the California Endowment to the South Asian Network for primary prevention of domestic violence and a $\$ 20,000$ award by the San Francisco Foundation in 2009 to Latina Center for Primero Nuestros Niños/Our Children First, a parenting education program for Latina survivors of family violence with children ages $0-5$ in Contra Costa County.

\section{Other Populations}

Examples of grants made to benefit other population groups include a $\$ 175,000$ grant from the Robert Wood Johnson Foundation to Asian Women's Shelter Project to evaluate, through research, an Intimate Partner Violence (IPV) prevention program for lesbian, gay, bisexual, and transsexual immigrants and refugees in San Francisco; a $\$ 35,000$ grant from the Zellerbach Family Foundation to Narika-an organization serving domestic violence survivors from South Asia-to foster the economic independence and leadership development of South Asian immigrant women through the provision of education and mentoring in leadership development, career counseling, English as a Second Language, and personal financial management; as well as two grants from the Verizon Foundation and Greater Milwaukee Foundation to the San Francisco-based Tides Center to support the A Call to Men project, which works to create a world where all men and boys are loving and respectful and all women and girls are valued and safe. 


\section{FUNDING BY TYPES OF SUPPORT}

Most grants awarded to address domestic violence in California targeted specific programs and projects (62.8 percent), and a smaller share (18.2 percent) were for general operating support. Compared to overall grantmaking by the nation's foundation community, support to California recipient organizations to address domestic violence was much more likely to focus on program support (62.8 percent versus 50.7 percent) while funding in this space was markedly less likely to focus on capital support (2.8 percent versus 12.6 percent) and research (1.3 percent versus 14.9 percent).

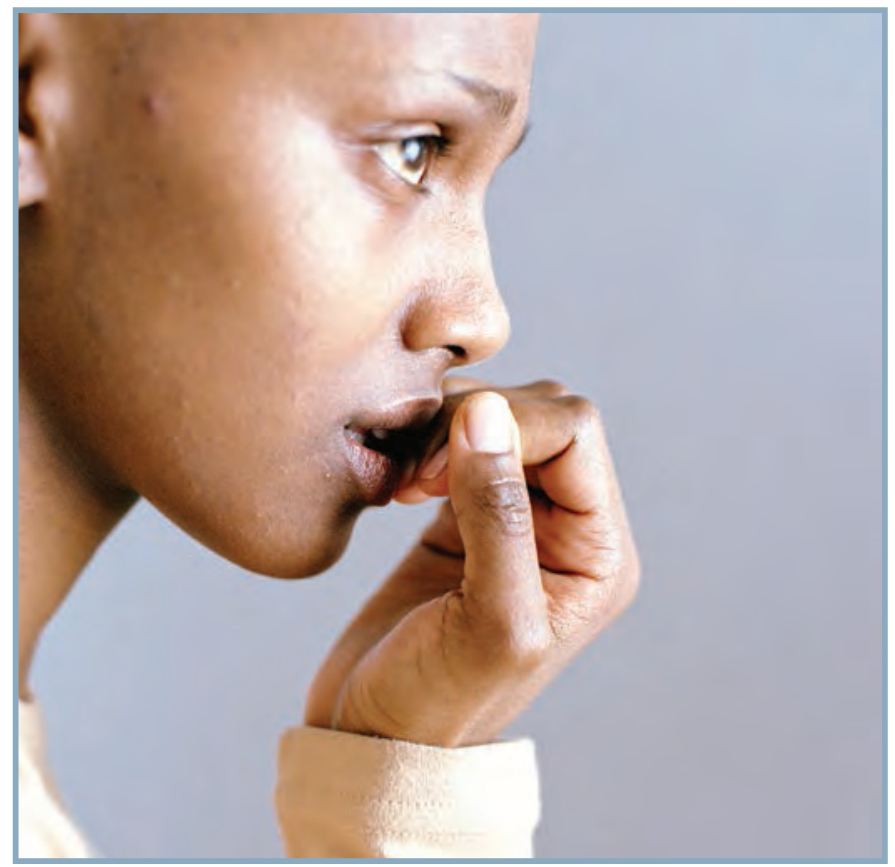

Funding by Types of Support, 2009-2011

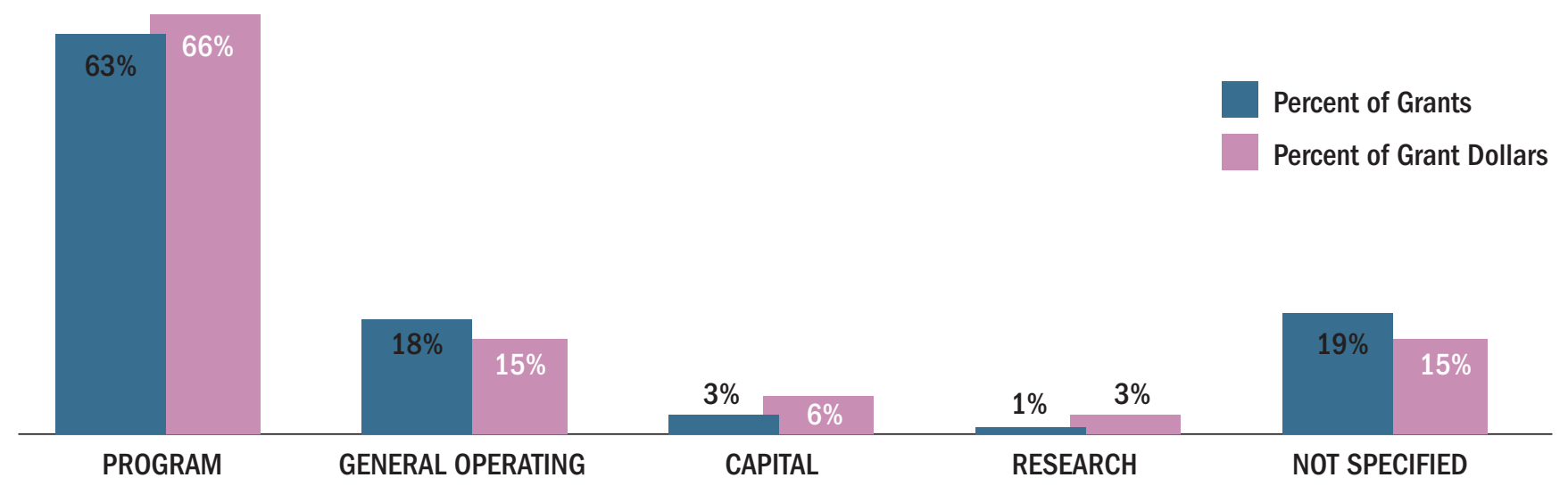

Source: The Foundation Center, 2014. Based on all grants of $\$ 10,000$ or more awarded by a sample of 1,000 larger foundations. See Table 6 of the Appendix for a ful breakdown of domestic violence-related funding in California by types of support. 


\section{ABOUT THE FOUNDATION CENTER GRANTS SAMPLE}

The information presented in this report is based on the Foundation Center's annual research grants sets. Each set includes all grants of $\$ 10,000$ or more awarded to organizations by the roughly 1,000 largest U.S. foundations by total giving. The sample accounts for roughly half of the total grant dollars awarded by the universe of independent, corporate, community, and grantmaking operating foundations.

Giving amounts are based on amount paid for the majority of foundations included in the set (72 percent), while the total amount authorized (whether it is paid during a single year or over several installments over a period of years) is used for the balance of the foundations included.
For the purposes of this report, we included only grants made to California-based organizations for domestic violence-related work domestically (i.e., all grants for International work were excluded). Therefore, any grants that benefited Californians but were awarded to organizations in another state are excluded. Also, some grants may have been awarded to California-based organizations that do work outside of the state, which are included in the analyses.

The issue focus, types of support and population group data reported in this brief are mostly based on grant descriptions provided by foundations. When detailed grant descriptions are not available, grants are coded based on a recipient organization's issue and population group focus, if available.

\section{ENDNOTES}

1. Black, M.C., Basile, K.C., Breiding, M.J., Smith, S.G., Walters, M.L., Merrick, M.T., Chen, J., \& Stevens, M.R. (2011). The National Intimate Partner and Sexual Violence Survey (NISVS): 2010 Summary Report. Atlanta, GA: National Center for Injury Prevention and Control, Centers for Disease Control and Prevention. (cdc.gov/violenceprevention/pdf/ nisvs report2010-a.pdf)

2. State of California Department of Justice, CJSC Statistics: Domestic Violence-Related Calls for Assistance (oag.ca.gov/crime/cjsc/stats/ domestic-violence)

3. National Network to End Domestic Violence (2012). Domestic Violence Counts 2011: A 24-Hour Census of Domestic Violence Shelters and Services. (nnedv.org/downloads/Census/DVCounts2011/ DVCounts11_NatIReport_Color.pdf)

4. Grants data for Blue Shield of California Foundation is based on year a grant was paid and not year authorized. Therefore, not reflected in the 2011 figures is an additional $\$ 4.6$ million in grants authorized by Blue Shield of California Foundation to address domestic violence in California.

5. For the purposes of this analysis, we included all dollars that were awarded to California under the Violence Against Women Act (VAWA), Victims of Crimes Act (VOCA) and Family Violence Prevention Services Act (FVSPA), which include funds allocated for domestic violence services. Because of this, the total funding from federal sources explicitly to address domestic violence is over-estimated.

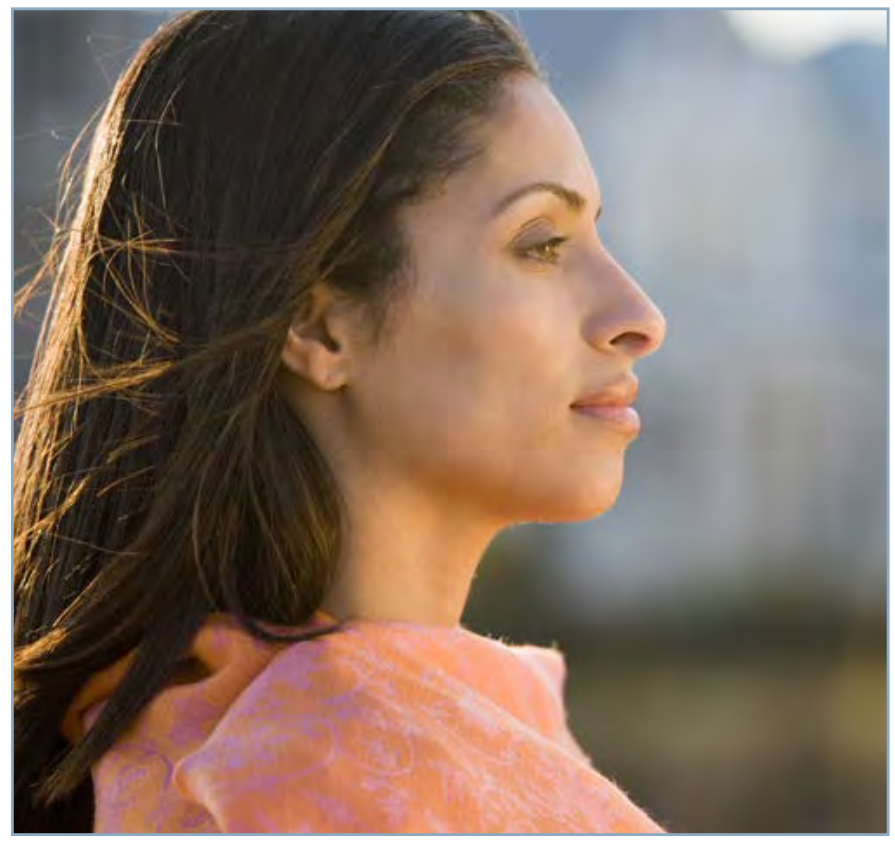




\section{APPENDIX}

\section{Table 1. TOP 50 FOUNDATIONS BY GIVING TO ADDRESS DOMESTIC VIOLENCE IN CALIFORNIA, 2009-2011}

FOUNDATION

1. Blue Shield of California Foundation

2. Robert Wood Johnson Foundation

3. Verizon Foundation

4. The California Endowment

5. Weingart Foundation

6. San Francisco Foundation

7. Orange County Community Foundation

8. Ralph M. Parsons Foundation

9. Silicon Valley Community Foundation

10. William and Flora Hewlett Foundation

11. Kresge Foundation

12. NoVo Foundation

13. David and Lucile Packard Foundation

14. Ahmanson Foundation

15. San Diego Foundation

16. The California Wellness Foundation

17. Walter and Elise Haas Fund

18. John and Lisa Pritzker Family Fund

19. Marin Community Foundation

20. Allstate Foundation

21. Pacific Life Foundation

22. Macy's Foundation

23. Santa Barbara Foundation

24. Community Foundation Sonoma County

25. Newman's Own Foundation

26. Sunshine Lady Foundation

27. Grove Foundation

28. Annenberg Foundation

29. Leichtag Foundation

30. Eisner Foundation

31. Wood-Claeyssens Foundation

32. Bella Vista Foundation

33. Wells Fargo Foundation

34. Carrie Estelle Doheny Foundation

35. Sobrato Family Foundation

36. California Community Foundation

37. H. N. \& Frances C. Berger Foundation

38. Bank of America Charitable Foundation

39. East Bay Community Foundation

40. Howard Charitable Foundation

41. Sierra Health Foundation

42. Sharon D. Lund Foundation

43. $Y \& H$ Soda Foundation

44. Richard and Rhoda Goldman Fund**

45. Jay and Rose Phillips Family Foundation

46. Dan Murphy Foundation

47. Charles and Helen Schwab Foundation

48. Green Foundation

49. Price Family Charitable Fund

50. Wal-Mart Foundation SUBTOTAL

All other foundations

TOTAL

\section{$\begin{array}{lcc}\text { STATE } & \begin{array}{c}\text { FOUNDATION } \\ \text { TYPE* }\end{array} & \begin{array}{c}\text { NO. OF } \\ \text { GRANTS }\end{array}\end{array}$

GRANTS

CA CS

NJ

CA

CA

CA

CA

CA

CA

CA

MI

CA

CA

CA

CA

CA

IL

CA

$\mathrm{OH}$

CA

NT

NC

CA

CA

$\mathrm{CA}$
$\mathrm{CA}$

CA

CA

CA

CA

CA

$\mathrm{CA}$
$\mathrm{NC}$

CA

CA

CA

$\mathrm{CA}$
$\mathrm{CA}$

$\mathrm{CA}$
$\mathrm{MN}$

CA

$\mathrm{CA}$

CA

CA

250

250

IN

CS

IN

IN

CM

IN

CM

IN

IN

IN

CM

IN

IN

CM

CS

CS

CS

CM

$\mathrm{CM}$

CS

OP

IN

IN

IN

IN

IN

IN

CM

IN

CS

CM

IN

IN

IN

IN

IN

IN

IN

IN

IN

\section{AMOUNT}

$\$ 12,957,176$

\section{$2,893,153$}

$2,598,511$

$2,517,025$

$1,715,000$

$1,515,800$

$1,436,900$

$1,160,000$

$1,127,889$

$1,100,000$

$1,000,000$

825,000

800,000

775,900

603,500

435,000

385,000

378,000

350,456

320,000

315,000

305,000

301,000

288,100

285,000

270,001

261,978

256,857

256,000

250,000

240,000

210,000

205,000

195,000

184,500

179,300

176,500

161,585

160,000

160,000

148,335

143,154

120,000

115,000

105,000

100,000

100,000

90,000

85,000

85,000

$\$ 40,646,620$

$1,411,710$

$\$ 42,058,330$

GIVING FOR DOMESTIC VIOLENCE

IN CALIFORNIA AS \% OF

FOUNDATION'S OVERALL GIVING

$\%$

30.8

$30.8 \quad 15.1$

$\begin{array}{ll}6.9 & 0.2\end{array}$

$\begin{array}{ll}6.9 & 0.2 \\ 6.2 & 2.2\end{array}$

$\begin{array}{ll}6.0 & 0.6\end{array}$

$\begin{array}{ll}6.0 & 0.6 \\ 4.1 & 2.1\end{array}$

$\begin{array}{ll}3.6 & 0.7\end{array}$

$3.4 \quad 2.3$

$\begin{array}{ll}3.4 & 2.3 \\ 2.7 & 2.3\end{array}$

$\begin{array}{ll}2.7 & 0.2\end{array}$

$\begin{array}{ll}2.7 & 0.2 \\ 2.7 & 0.2\end{array}$

$2.4 \quad 0.2$

$2.0 \quad 1.2$

$\begin{array}{ll}2.0 & 1.2 \\ 1.9 & 0.1\end{array}$

$\begin{array}{ll}1.8 & 0.6\end{array}$

$\begin{array}{ll}1.8 & 0.6 \\ 1.4 & 1.2\end{array}$

$\begin{array}{ll}1.4 & 0.4\end{array}$

$\begin{array}{ll}0.9 & 1.1\end{array}$

$\begin{array}{ll}0.9 & 1.6\end{array}$

$\begin{array}{ll}0.9 & 0.2\end{array}$

$\begin{array}{ll}0.9 & 0.2 \\ 0.8 & 1.0\end{array}$

$\begin{array}{ll}0.8 & 1.0 \\ 0.8 & 3.8\end{array}$

$\begin{array}{ll}0.7 & 0.8\end{array}$

$\begin{array}{ll}0.7 & 0.8 \\ 0.7 & 1.6\end{array}$

$0.7 \quad 1.0$

$\begin{array}{ll}0.7 & 0.3\end{array}$

$\begin{array}{ll}0.7 & 0.3 \\ 0.7 & 2.0\end{array}$

$\begin{array}{ll}0.6 & 1.0\end{array}$

$\begin{array}{ll}0.6 & 1.0 \\ 0.6 & 0.1\end{array}$

$\begin{array}{ll}0.6 & 1.2 \\ 0.6 & 1.3\end{array}$

$0.6 \quad 1.3$

$\begin{array}{ll}0.6 & 1.3 \\ 0.6 & 0.5\end{array}$

$0.5 \quad 3.3$

$\begin{array}{ll}0.5 & 3.3 \\ 0.5 & 0.1\end{array}$

$\begin{array}{ll}0.5 & 1.0\end{array}$

$\begin{array}{ll}0.4 & 1.9\end{array}$

$\begin{array}{ll}0.4 & 1.9 \\ 0.4 & 0.3\end{array}$

$\begin{array}{ll}0.4 & 0.3 \\ 0.4 & 0.8\end{array}$

$\begin{array}{ll}0.4 & 0.0\end{array}$

$\begin{array}{ll}0.4 & 0.0 \\ 0.4 & 0.2\end{array}$

$\begin{array}{ll}0.4 & 1.0\end{array}$

$\begin{array}{ll}0.4 & 1.0 \\ 0.4 & 1.7\end{array}$

$0.3 \quad 1.0$

$\begin{array}{ll}0.3 & 2.9\end{array}$

$\begin{array}{ll}0.3 & 0.1\end{array}$

$\begin{array}{ll}0.3 & 0.6 \\ 0.2 & 0.4\end{array}$

$\begin{array}{ll}0.2 & 0.4 \\ 0.2 & 0.2\end{array}$

$\begin{array}{ll}0.2 & 0.9\end{array}$

$\begin{array}{ll}0.2 & 0.9 \\ 0.2 & 0.3\end{array}$

$\begin{array}{ll}0.2 & 0.0\end{array}$

$\begin{array}{rrr}2 & 85,000 & 0.2 \\ 782 & \$ 40,646,620 & 96.6 \\ 82 & 1,411,710 & 3.4 \\ 864 & \$ 42,058,330 & 100.0\end{array}$

Source: The Foundation Center, 2014. Based on all grants of $\$ 10,000$ or more awarded by a sample of 1,000 larger foundations. $* I N=$ Independent Foundation; $\mathrm{CM}=$ Community Foundation; $\mathrm{CS}=$ Corporate Foundation; OP=Operating Foundation.

**After 60 years of philanthropy, the Richard and Rhoda Goldman Fund closed its doors in 2012. 


\section{Table 2. TOP 50 RECIPIENTS OF FUNDING TO ADDRESS DOMESTIC VIOLENCE IN CALIFORNIA, 2009-2011}

RECIPIENT ORGANIZATION

1. Futures Without Violence

2. Family Justice Center Alliance

3. Women's Foundation of California

4. California Partnership to End Domestic Violence

5. Jenesse Center

6. Community Overcoming Relationship Abuse

7. CompassPoint Nonprofit Services

8. Human Options

9. Interval House

10. Next Door Solutions to Domestic Violence

11. Domestic Violence Solutions for Santa Barbara County

12. House of Ruth

13. Center for Domestic Peace

14. South Bay Community Services

15. Asian Women's Shelter Project

16. WomenShelter of Long Beach

17. Shelter from the Storm

18. Rainbow Services

19. Convent of the Good Shepherd Shelter

20. Laura's House

21. La Casa de las Madres

22. STAND! Against Domestic Violence

23. South Asian Network

24. Community Resource Center

25. Cornerstone Community Development Corporation

26. Los Angeles House of Ruth

27. Center for Community Solutions

28. University of California

29. Marjaree Mason Center

30. Support Network for Battered Women

31. Shelter Outreach Plus

32. Haven Hills

33. 1736 Family Crisis Center

34. High Desert Domestic Violence Program

35. Women's Transitional Living Center

36. A Window Between Worlds

37. Jewish Family Service of Los Angeles

38. University of California

39. My Sister's House

40. Family Violence Law Center

41. Women's Community

42. Swords to Plowshares

43. Northern California Institute for Research and Education

44. YWCA San Gabriel Valley

45. Women Organized to Make Abuse Non-Existent

46. A Safe Place

47. Riverside County Coalition for Alternatives to Domestic Violence

48. Women's Center of San Joaquin County

49. Family Justice Center of Sonoma County

50. Saint John's Shelter for Women and Children SUBTOTAL

All other recipients TOTAL

NO. OF
GRANTS AMOUNT

San Diego

San Francisco

Sacramento

Los Angeles

Burlingame

Oakland

Irvine

Long Beach

San Jose

Santa Barbara

Claremont

San Rafael

Chula Vista

San Francisco

Long Beach

Palm Desert

San Pedro

Los Angeles

Ladera Ranch

San Francisco

Concord

Artesia

Encinitas

San Leandro

Los Angeles

San Diego

San Francisco

Fresno

Sunnyvale

Marina

Canoga Park

Los Angeles

Victorville

Orange

Venice

Los Angeles

Los Angeles

Sacramento

Oakland

Los Angeles

San Francisco

San Francisco

Covina

San Francisco

Oakland

Riverside

Stockton

Santa Rosa

Sacramento

$\$ 6,011,443$

$2,676,400$

$1,772,343 \quad 4.2$

$1,308,900 \quad 3.1$

$955,000 \quad 2.3$

$929,644 \quad 2.2$

$874,465 \quad 2.1$

$817,800 \quad 1.9$

$760,500 \quad 1.8$

$\begin{array}{ll}732,279 & 1.7\end{array}$

$\begin{array}{ll}721,000 & 1.7\end{array}$

614,500

596,650

564,750

553,000

$552,500 \quad 1.3$

548,357

$505,000 \quad 1.2$

$505,000 \quad 1.2$

$455,410 \quad 1.1$

$437,075 \quad 1.0$

428,660

$425,000 \quad 1.0$

$411,000 \quad 1.0$

405,075

$390,000 \quad 0.9$

$380,506 \quad 0.9$

$378,000 \quad 0.9$

$359,000 \quad 0.9$

$342,633 \quad 0.8$

$\begin{array}{ll}335,000 & 0.8\end{array}$

$\begin{array}{ll}319,400 & 0.8\end{array}$

$315,000 \quad 0.8$

$\begin{array}{ll}295,000 & 0.7\end{array}$

$\begin{array}{ll}285,500 & 0.7\end{array}$

$\begin{array}{ll}285,000 & 0.7\end{array}$

$273,267 \quad 0.7$

$264,207 \quad 0.6$

$260,146 \quad 0.6$

$260,000 \quad 0.6$

$250,001 \quad 0.6$

$250,000 \quad 0.6$

$250,000 \quad 0.6$

$244,000 \quad 0.6$

$240,975 \quad 0.6$

$240,000 \quad 0.6$

$240,000 \quad 0.6$

$225,415 \quad 0.5$

$225,000 \quad 0.5$

$218,000 \quad 0.5$

$\$ 31,687,801$

$10,370,529 \quad 24.3$

$\$ 42,058,330 \quad 100.0$

Source: The Foundation Center, 2014. Based on all grants of $\$ 10,000$ or more awarded by a sample of the 1,000 largest foundations by total giving. 


\section{Table 3. TOP CALIFORNIA COUNTIES BY DOLLARS RECEIVED TO ADDRESS DOMESTIC VIOLENCE, 2009-2011}

COUNTY

1. San Francisco

2. Los Angeles

3. San Diego

4. Alameda

5. Sacramento

6. Santa Clara

7. Orange

8. San Mateo

9. Riverside

10. Santa Barbara

11. Marin

12. San Bernardino

13. Contra Costa

14. Monterey

15. Sonoma

16. Fresno

17. San Joaquin

18. Sutter

19. Stanislaus

20. Kern

21. El Dorado

22. Humboldt

23. Ventura

24. Del Norte

25. Tulare

26. Mono

27. Imperial

28. San Luis Obispo

29. Santa Cruz

30. Inyo

31. Shasta

32. Yolo

33. Placer

34. Solano

35. Butte

36. Napa

37. Tehama

38. Lassen

39. Mariposa

40. Mendocino

41. Siskiyou

42. Plumas

43. Trinity

44. Tuolumne

45. Amador

46. Lake

47. Nevada

48. Calaveras Kings

Madera

Modoc

San Benito
AMOUNT

$\$ 11,538,871$

$8,693,739$

4,526,156

$2,718,080$

$2,215,126$

$1,847,907$

$1,741,864$

$1,179,644$

968,357

836,000

596,650

564,000

548,660

495,000

407,100

369,000

265,415

188,576

143,720

140,000

135,000

130,000

130,000

120,000

112,000

110,000

105,000

105,000

92,850

84,615

80,000

75,000

70,000

60,000

55,000

55,000

55,000

50,000

50,000

45,000

45,000

40,000

40,000

40,000

30,000

30,000

30,000

20,000

20,000

20,000

20,000

20,000
NO. OF GRANTS

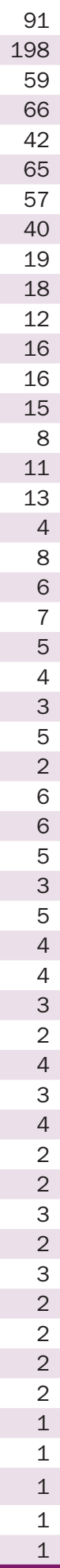

Source: The Foundation Center, 2014. Figures based on a sample of over 1,000 larger foundations. 


\section{Table 4. DISTRIBUTION OF GRANTS TO ADDRESS DOMESTIC VIOLENCE IN CALIFORNIA BY ISSUE FOCUS, 2009-2011}

\section{SUBJECT}

DOLLAR VALUE OF GRANTS

Arts and Culture

Media and Communications

Visual Arts/Architecture

Total Arts and Culture

AMOUNT

$\%$

NUMBER OF GRANTS

Education

Elementary and Secondary

Higher Education

$\begin{array}{rrrr}25,000 & 0.1 & 1 & 0.1 \\ 285,000 & 0.7 & 10 & 1.2 \\ \$ 310,000 & 0.7 & 11 & 1.3\end{array}$

Graduate and Professional

Adult and Continuing

Student Services

40,000

0.1

0.5

212,123

0.5

264,207

0.6

60,000

0.1

88,499

0.2

50,000

0.1

$\$ 626,330$

1.5

Total Education

$\$ 15,000$

$<0.1$

$<0.1$

0.5

0.1

0.2

0.2

$\$ 15,000$

$<0.1$

0.3

1.6

Environment and Animals

Total Environment and Animals

Health

General and Rehabilitative

Policy, Management, and Information

Hospitals and Medical Care

Reproductive Health Care

Public Health

Mental Health

Total Health

$\$ 220,000$
130,000
$1,130,000$
$11,450,937$
$2,724,185$
$\$ 14,350,122$

0.5

0.3

2.7

27.2

6.5

34.1

$\$ 33,764,898$

80.3

35.6

28.8

12,127,696

553,000

1.3

2,965,423

$6,630,673$

7.1

$\$ 41,719,610$

15.8

99.2

$\$ 610,000$

1.5

$$
1.1
$$

1,719,574

4.1

$\$ 2,644,574$

6.3

$1,312,831$
$\$ 1,312,831$
$\$ 402,500$

3.1

3.1

1.0

$\begin{array}{rr}4 & 0.5 \\ 5 & 0.6 \\ 3 & 0.3 \\ 159 & 18.4 \\ 50 & 5.8 \\ 205 & 23.7\end{array}$

23.7

87.8

26.7

22.2

0.9

0.9

12.2

98.0

847

1.7

0.7

1.4

3.6

Social Sciences

Social Science and Economics

Total Social Sciences

Religion

$\$ 402,500$

$\begin{array}{rr}15 & 1.7 \\ 6 & 0.7 \\ 12 & 1.4 \\ 31 & 3.6\end{array}$

Source: The Foundation Center, 2014. Figures based on a sample of over 1,000 larger foundations. Grants may focus on multiple sub-issues; therefore some grants may be counted in more than one area. 


\section{Table 5. GRANTS TO ADDRESS DOMESTIC VIOLENCE IN CALIFORNIA BY POPULATION GROUP, 2009-2011}

\begin{tabular}{|c|c|c|c|c|}
\hline POPULATION GROUP & AMOUNT & $\%$ & NO. OF GRANTS & $\%$ \\
\hline Aging/Elderly/Senior Citizens & $\$ 30,000$ & 0.1 & 3 & 0.3 \\
\hline Children \& Youth & $30,817,084$ & 73.3 & 635 & 73.5 \\
\hline Crime or Abuse Victims & $41,618,330$ & 99.0 & 855 & 99.0 \\
\hline Economically Disadvantaged & $14,340,884$ & 34.9 & 302 & 35.0 \\
\hline Poor, Indigent-General & $12,081,309$ & 28.7 & 242 & 28.0 \\
\hline Migrant Workers & 55,000 & 0.1 & 2 & 0.2 \\
\hline Ethnic or Racial Minorities & $7,800,782$ & 18.9 & 139 & 16.1 \\
\hline General & $3,971,501$ & 9.4 & 53 & 6.1 \\
\hline Asians \& Pacific Islanders & $2,350,081$ & 5.6 & 54 & 6.3 \\
\hline African Americans \& Blacks & 10,000 & $<0.1$ & 1 & 0.1 \\
\hline LGBT & 175,000 & 0.4 & 1 & 0.1 \\
\hline Immigrants \& Refugees & $2,741,929$ & 6.5 & 61 & 7.1 \\
\hline Men \& Boys & $1,463,499$ & 3.5 & 10 & 1.2 \\
\hline Military \& Veterans & 817,123 & 1.9 & 9 & 1.0 \\
\hline Offenders \& Ex-Offenders & 60,000 & 0.1 & 3 & 0.3 \\
\hline People with AIDS & 20,000 & $<0.1$ & 1 & 0.1 \\
\hline People with Disabilities & 325,000 & 0.8 & 7 & 0.8 \\
\hline Single Parents & 878,153 & 2.1 & 4 & 0.5 \\
\hline Substance Abusers & 425,000 & 1.0 & 8 & 0.9 \\
\hline
\end{tabular}

Source: The Foundation Center, 2014. Based on all grants of $\$ 10,000$ or more awarded by the top 1,000 foundations by total giving. Figures represent only grants awarded to recipient organizations that could be identified as serving specific populations or grants whose descriptions specified a benefit for a specific population. These figures do not reflect all giving benefiting these groups. In addition, grants may benefit multiple population groups, (e.g., a grant for homeless children,) and would therefore be counted more than once. 


\section{Table 6. GRANTS TO ADDRESS DOMESTIC VIOLENCE IN CALIFORNIA BY TYPES OF SUPPORT, 2009-2011}

\begin{tabular}{|c|c|c|c|c|}
\hline \multirow[b]{2}{*}{ TYPES OF SUPPORT } & \multicolumn{2}{|c|}{ DOLLAR VALUE OF GRANTS } & \multicolumn{2}{|c|}{ NUMBER OF GRANTS } \\
\hline & AMOUNT & $\%$ & No. & $\%$ \\
\hline General Support & $\$ 6,198,893$ & 14.7 & 157 & 18.2 \\
\hline Management development & 520,075 & 1.2 & 16 & 1.9 \\
\hline General/operating support & $5,648,818$ & 13.4 & 139 & 16.1 \\
\hline Equipment & 174,400 & 0.4 & 6 & 0.7 \\
\hline Building/renovations & $1,679,000$ & 4.0 & 13 & 1.5 \\
\hline Capital campaigns & 375,001 & 0.9 & 3 & 0.3 \\
\hline Program Support & $27,828,159$ & 66.2 & 543 & 62.8 \\
\hline Curriculum development & 20,000 & $<0.1$ & 1 & 0.1 \\
\hline Conferences/seminars & 10,000 & $<0.1$ & 1 & 0.1 \\
\hline Electronic media/online services & 175,975 & 0.4 & 3 & 0.3 \\
\hline Research & $1,255,984$ & 3.0 & 11 & 1.3 \\
\hline Student Aid Funds & 378,000 & 0.9 & 2 & 0.2 \\
\hline Internship funds & 378,000 & 0.9 & 2 & 0.2 \\
\hline Other & $2,855,000$ & 6.8 & 10 & 1.2 \\
\hline Technical assistance & $2,500,000$ & 5.9 & 7 & 0.8 \\
\hline Emergency funds & 150,000 & 0.4 & 1 & 0.1 \\
\hline Program evaluation & 205,000 & 0.5 & 2 & 0.2 \\
\hline
\end{tabular}

Source: The Foundation Center, 2014. Figures based on a sample of over 1,000 larger foundations. Grant may occasionally be for multiple types of support and would therefore be counted more than once.

*Qualifying types of support are tracked in addition to basic types of support, e.g., a challenge grant for construction, and are therefore represented separately. 
